\title{
The Effect of Top Management Support and Internal Control of the Accounting Information Systems Quality and Its Implications on the Accounting Information Quality
}

\author{
Sri Dewi Anggadini \\ Doctoral Student Accounting Department, Faculty of Economics and Business \\ Padjadjaran University Bandung, West Java, Indonesia \\ dewianggadini8@gmail.com
}

\begin{abstract}
This study empirically examined the influences of the top management support and of the internal control on the accounting information system quality system. Besides, the accounting information system quality has an impact on the accounting information quality. To collect the data, a research instrument was prepared to participant. Using survey information collected from forty seven (47) Baitulmal Wattamwil (BMT) in West Java Indonesia those are applied accounting information system, this study uses path analysis method. The results of the test show that the top management supports and the internal control have significant influences on the accounting information system quality. Besides, the accounting information system quality has an impact on the accounting information quality as well.
\end{abstract}

Keywords: Top management support, internal control, accounting information system quality, accounting information quality

\section{Introduction}

Information is data that has been processed so that it has a high value (Wilkinson et al., 2000:5). Information plays an important role in all aspects of human life, both individual and organization (Azhar, 2008:11). The role of information is one of the strategic resources for the survival of the company to be managed effectively so that organizations gain strategic advantage, tactical advantage and operational advantage (McLeod \& Schell, 2007:29). Accounting information is one of the reliable information and can be used as a basis for decision-making (Hall, 2011:11) and assists external parties to evaluate the performance, monitoring activities, as well as a measure for policy purposes (regulatory measures) (Hansen et al., 1995 : 35). Accounting information results from the accounting process (Azhar, 2008:65) are generally presented in the form of financial statements (Kieso et al., 2012:5). Accounting information quality is suitable accounting information (fit) with user needs (Wang \& Strong, 1996). McLeod \& Schell (2007:46) and Gelinas et al. (2012:19) says that the quality of information should have characteristics of relevancy, accuracy, timeliness and completeness. According to Indra (2010:125) the public sector organizations in Indonesia are generally producing quality accounting information that has not been good, sometimes is not reliable, and can only be used as a decision-making consideration for the period after the reporting period. This is shown with a disclaimer opinion on BPK audit for central government financial statements (Audited) 2004 to 2007 (Anwar, 2009) and for the financial statements 8 (eight) ministries/government agencies in 2009 (Hadi, 2010) as well as for financial statements of the finance ministry in 2005-2009 (Agus, 2010). The condition, for certain, requires each agency information system improvements in governance (Herry, 2010) and strengthen the synergies information system (Hadi, 2012) because through the application of quality information systems, can optimize the operation (Shebab, 2004). For certain, if the quality of information produced is not qualified it is because of the quality information system (Sacer et al., 2006:62).

Information system is a tool that provides the necessary information to all interested parties (Azhar, 2008:58) and as a manager's tool to cope with the change (Laudon \& Laudon, 2014:43). Therefore, the information system must be accepted and used by all employees in the organization (Laudon \& Laudon, 2014:45). Quality information systems can mean a successful information system (managed) or effective (DeLone et al., 2003). According to Ralph et al. (2010:57) states that a quality information system is usually flexible, efficient, accessible and timely. In fact, accounting information systems applied to public and private sector organizations in Indonesia have not been good. It was stated by Anwar Nasution (2007) which says that the improvement of national accounting information system is sluggish. The low quality of accounting information systems also occurs in the organization of State Owned Enterprises 
(SOEs). From the analysis of the 2005-2011 BPK audit found a total of 24 SOEs potentially corrupt state institutions (Uchok Sky Khadafi, 2012). Similar conditions, also occurs in treasury Wattamwil (BMT) which has limitations in information systems.

To achieve the quality of the information system, it takes commitment from top management (Doll \& Deng, 2001), as well as the involvement of top management as a user in the development of information systems (Zviran et al., 2005), so that users can receive and use information systems which are developed and ultimately can increase users' satisfaction (DeLone \& McLean, 1992). This opinion is supported by the results of research McGill (2003) and Wixom \& Todd (2005). Top management support in the development of accounting information systems can be committed in the form of time, money, and resources to support the development of information systems that occur in long-term partnerships and companies can also ongoing in stable process (Mark et al., 2012). The quality of accounting information systems is influenced by internal control factors. The internal controls in the context of this study means methods, policies and procedures which are established/constructed to provide reasonable assurance to management that the activity and function of accounting information system facilities are reasonable to hold input activities, processes and the activities to produce quality accounting information to user and storage activities (Elder et al., 2010:290). Messier \& Prawit (2010:290). The phenomenon regarding to the lack of management support and internal control is seen in the company of many cases, in general, are the weak commitment of the highest to the lowest leadership in eliminating corruption (Taufikurahman, 2011), in the absence of equitable distribution of responsibilities, weak internal controls and a lack of supervision of top management (Halim, 2011) are reflected in the weakness of the systems and procedures (Difi, 2012). Based on the description above, the author is interested in doing research with the title "The Effect of Top Management Support and Internal Control of the Accounting Information Systems Quality and Its Implications on the Accounting Information Quality. The research was conducted at the Baitulmal Wattamwil (BMT) West Java Indonesia.

\section{Literature Review}

Top Management Support: Raymond (2006) define top management support is that only project management success (on-time on-budget) is emphasised by all stakeholders and top management support has been neglected. The similiar to Raymond (2006), Sheth (2010:50) explain that top management support is the factor that determines the tipping point between potential succes and failure when developing and implementing business continuity of the management project and system. From the above, it can be concluded that the top management support is the involvement of the top management for the provision of guidelines with a commitment in terms of time, cost, and resources to support activities within an organization via information systems in decision making for the achievement of objectives in an organization (Raymond, 2006; Sheth, 2010:50; Robbins et al., 2012:34; Mahring, 2002:48; Shead, 2002:52; Chen \& Paulraj, 2004; Jarvenpaa \& Ives, 1991; Hashmi, 2004; Choe, 1996; Doll, 1985; Bhanu et al., 2004; Mark et al., 2012). The Dimensions of the top management support in this study consisted of: (1) Evaluate the current and future use of IT; (2) Direct preparation and implementation of plans and policies to ensure that the use of IT meets business objectives; (3) Monitor conformance to policies and performance against the plans.

Internal Control: Elder et al. (2010:290) menyatakan a system of internal control consists of policies and procedures designed to provide management with reasonable assurance that company achieves its objectives and goals. These policies and procedures are often called controls, and collectively they comprise the entity's internal control. Further Messier \& Prawit (2010:290) said also that the internal control is design and affected by an entity's board of directors, management, and other personnel, designed to provide reasonable assurance about the achievement of entity's objectivities in the following categories: (1) Realibility of finacial reporting, (2) Effectiveness and efficiency of operations, and (3) Compliance with applicable laws and regulations. From the statement above, the concept of internal control aimed at the concept of information system quality, so that means as a method of internal controls, policies and procedures established / constructed to provide reasonable assurance to management that the activity and function of accounting information system facilities are fair to hold the input activity, processes and activities in order to produce accounting information quality ( (Elder et al., 2010:290; Messier \& Prawit, 2010:290; Bodnar \& Hopwood, 2010:138). Dimensions of internal control in this study consisted of: (1) The control environment; (2) The entity's risk assessment process; (3) The control activities; (4) The Information Systems and communications; (5) Monitoring (Bodnar \& Hopwood, 2010:149; Nash \& Heagy, 1993:485). 
Accounting Information System Quality: Fundamental role of accounting information systems in organizations is to produce accounting information quality (Azhar, 2008:374). An accounting information system quality is defined as a form of a statement about the conditions in which accounting information system can generate accounting information according to user needs. Accounting information quality obtained from the application of the accounting information systems quality (Sacer et al., 2006:6). Ralph et al. (2010:57) menyatakan a quality information system is usually flexible, efficient, accessible, and timely. Further, an information system that blend technical efficiency with sensitivity to organizational and human needs, leading to higher job satisfaction and productivity. From these statements, the accounting information system quality can generate accounting information according to user needs (Azhar, 2008:374; Sacer et al., 2006:6; Ralph et al., 2010:57). The dimensions and indicators of accounting information system quality in this study consists of: (1) Flexibility, (2) Efficiency and (3) Accessibility (Azhar, 2008:374; Sacer et al., 2006:6; DeLone et al., 2003; Ralph et al., 2010:57).

Accounting Information Quality: According to McLeod \& Schell (2007:86) information should be available for problem solving brfore crisis situasions develop or opportunities are lost. The user should be to obtain information that describes what is happening now, in addition to what happened in the past. Information that arrives the decision is made has no value. O'Brien \& Marakas (2008:360) explain that information of high quality, that is information products whose charactersitics, attributes, or qualities make the information more valuable to them. It is useful to think of information as having the three dimension of time, content and form. From the above, it can be said that the accounting information quality is useful information for decision makers who have the criteria for accurate, relevant, timely and complete (McLeod \& Schell, 2007:86; O’Brien \& Marakas, 2008:360; Azhar, 2008:14; Hall, 2011; Shipper \& Vincent, 2003:99; Eppler, 2003) where the four criteria used as dimension in this study.

Figure 1: Theoretical framework of the study

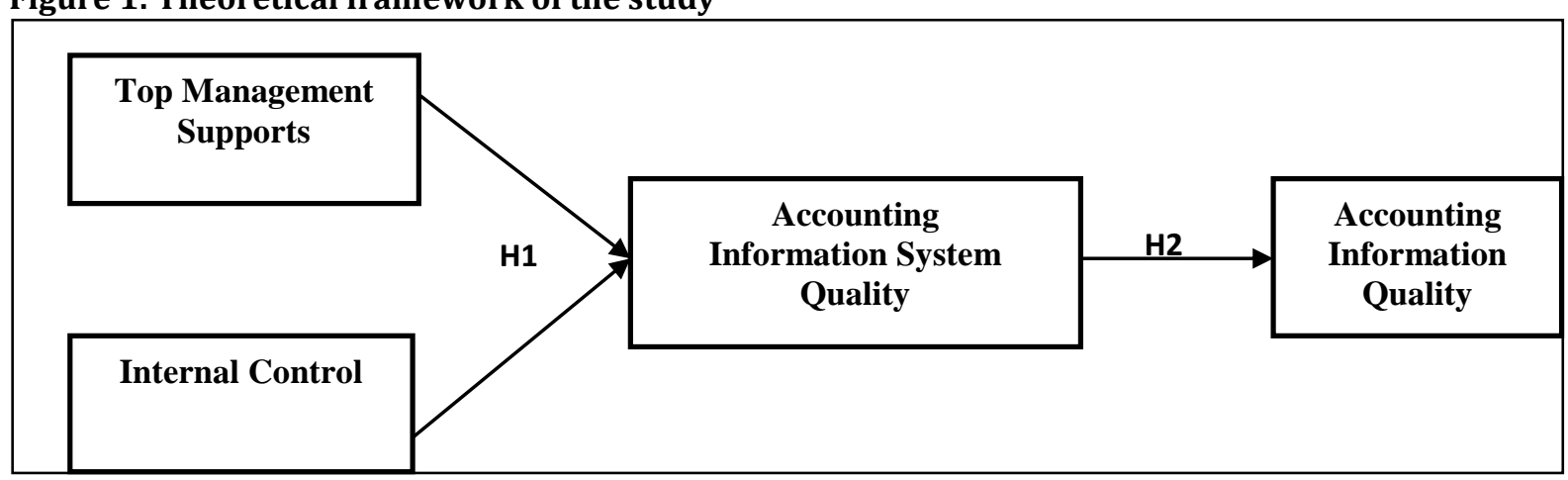

Theoretical Framework: Theoretical framework designed in this study is that the accounting information system quality is influenced by top management support. Mahring (2002: 56) states that many studies consider top management supports as one important factor of the studies' for achieving successful information system implementation. That is supported by the results of the studies of Ann et al. (2008); Rajeev Sharma et al. (2003); Bhanu et al. (2004); Mark et al. (2012) showing that the top management supports give powerful effect on adoption of accounting information system. The accounting information system is also influenced by internal control. The accounting information system is also influenced by internal control. Azhar (2008:117) stated that the internal controls necessary to ensure that the accounting information system works as it should so that the risk of deviation from its intended purpose will be avoided. Companies are required to develop the internal controls in order to provide adequate assurance that the financial statements are presented fairly (Arens et al., 2008:371). That is supported by the results of the studies of Iceman \& Hillson (1990). The accounting information quality is influenced by the accounting information system quality. This is supported by the result of the study showing that accounting information system enhances the truth of financial statements (Salehi et al., 2010). Thus, it is concluded that there is a relationship between accounting information system to report on the basis of information quality characteristics (Sacer et al., 2006). Nicolaou (2000) states, that the effectiveness of the accounting information system is measured by the satisfaction of the decision makers on the information quality produced by the accounting information system. To sum up, the study is aimed to determine the causal relationship between variables through tested hypothesis.

Hypothesis 1 : The accounting information system quality is significantly influenced by the top management supports and the internal control.

Hypothesis 2 : The accounting information quality is significantly influenced by the accounting information system quality. 


\section{Methodology}

Research methodology used in this study is method of survey with questionnaires as a tool. The units of analysis of the study are forty seven (47) Baitulmal Wattamwil (BMT) in West Java Indonesia. The study focuses on applying accounting information system and survey conducted on the units of analysis. Numbers of questionnaires are distributed to each company, one copy for one company. Respondents of this study are the leaders of management companies of the Baitulmal Wattamwil (BMT). The questionnaires are manipulated based on indicators using a Likert's summated rating. The questionnaires use closed questions format serving answered choices for variables that have clear indicators measured. Data analysis conducted in this study is descriptive and verificative. The answers from the respondents were treated as data and processed by statistical measures. The sincerity of the respondents' answers is crucial; therefore, the data were tested through a test of validity and reliability. Then, in order to analyze the data statistically, the ordinal data must be transformed into interval data using the successive interval method.

\section{Results and Discussion}

Result of Validity and Reliability Test: The questionnaire items used have been thought on the standard of validity and reliability. Validity and reliability test shows that the items used in the study are items whose correlation co-efficiency is not less than 0.30 and reliability co-efficiency recommended is not less than 0.70 . The measurement device to analyze of validity and reliability is SPSS version 20 programme.

Table 1: The Result of Recapitulation of Validity and Reliability Test

\begin{tabular}{llll}
\hline Variable & \multicolumn{1}{c}{ Range $\mathbf{r}_{\mathbf{s}}$} & Explanation & Reliability \\
\hline Top Management Supports & $0.469-0.636$ & All items valid & 0.7234 \\
Internal Control & $0.425-0.669$ & All items valid & 0.7531 \\
$\begin{array}{l}\text { Accounting Information } \\
\text { Quality }\end{array}$ & System $0.622-0.743$ & All items valid & 0.7284 \\
Accounting Information Quality & $0.582-0.774$ & All items valid & 0.7651 \\
\hline
\end{tabular}

The answers are treated as data and processed by statistical measures. The sincerity of the respondents' answers is crucial; therefore, the data were tested through a test of validity and reliability.

Table 2: Descriptive Analysis of Dimensions and Variables

\begin{tabular}{llll}
\hline Variables & Dimension & Percentage & Category \\
\hline Top Management & Evalute & 62,5 & Fair \\
Supports & Direct & 64,6 & Fair \\
& Monitor & 62,8 & Fair \\
Internal Control & Average variable & 63,7 & Fair \\
& The control environment & 65,4 & Fair \\
& The entity's risk & 64,3 & Fair \\
& assessment process & & \\
& The control activities & 64,8 & Fair \\
& The Information Systems & 63,6 & Fair \\
& and communications & & \\
Accounting & Monitoring & 65,4 & Fair \\
Information System & Average variable & 64,6 & Fair \\
& Flexible & 60,9 & Fair \\
& Efficient & 62,2 & Fair \\
Accounting & Accessible & 58,4 & Bad \\
Information Quality & Average variable & 60,2 & Fair \\
& Accuracy & 60,7 & Fair \\
& Relevant & 62,5 & Fair \\
& Timelines & 55,6 & Bad \\
& Completeness & 63,8 & Fair \\
& Average variable & 61,2 & Fair \\
\hline
\end{tabular}


Result of Descriptive Analysis: Descriptive analysis of variables covers top management supports, internal control, accounting information system quality and accounting information quality. To clarify variables, the study uses the actual percentage score of each dimension of the ideal score, then the data are interpreted into five categories: excellence, good, fair, bad, and worst. The variables are measured by using Likert's summated rating. Score is given in the answers then summated (Harun, 1994). The following summary table is presented the percentage value and category of each variable. Learning from table 3 , it is illustrated that the responds of the respondents to top management support may be considered as fair with score $63.7 \%$. It means that top management support constructed in Baitulmal Wattamwil (BMT) may be defined fair. Related to the internal control, the respondents respond that it is identified fair with score $64.6 \%$. It means that the internal control gives an enough support to the activities run. The same evaluation is seen in the accounting information system quality. The system is calculated fair with score $60.2 \%$ even though respondents gives bad responds on accessible $58.4 \%$. The condition gives an idea that accounting information system applied in the Baitulmal Wattamwil (BMT) is run fairly, but still has weaknesses in accessible. Besides, accounting information quality, in general, is valued to be fair with score $61.2 \%$ but has weakness in timeline; the information have been reported on time, the score is $55.6 \%$.

\section{The Result of Verifiable Analysis}

The Influence of the Top Management Supports and of the Internal Control on the Accounting Information System Quality and Its Implication on the Accounting Information Quality: To find out the influences of the top management supports and of the internal control on the accounting information system quality and its implication on the accounting information quality, this study uses path analysis. Before making conclusion on path causal-relationship, significant test on each path coefficient counted is conducted. The measurement scale of both caused and effect variables have to be below interval. By using succession interval methods, ordinal scale can be transformed into interval scale (Harun, 1994: 131). Here is the result of the test of $\mathrm{Y}$ and $\mathrm{Z}$ variables; $\mathrm{Y}$ stands for accounting information system quality and $\mathrm{Z}$ for accounting information quality.

Table 3: One-Sample Kolmogorov-Smirnov Test

\begin{tabular}{|c|c|c|c|}
\hline & & $\mathbf{Y}$ & $\mathbf{Z}$ \\
\hline$\overline{\mathrm{N}}$ & & 47 & 47 \\
\hline \multirow[t]{2}{*}{ Normal Parameters a.b } & Mean & 93.445782 & 58.5567349 \\
\hline & Std. Deviation & 23.81236 & 14.45807 \\
\hline Most Extreme & Absolute & .193 & .241 \\
\hline \multirow[t]{2}{*}{ Differences } & Positive & .148 & .167 \\
\hline & Negative & -186 & -249 \\
\hline Kolmogorof-Smirnov Z & & .991 & 1.475 \\
\hline Asymp.Sig. (2-tailed) & & .492 & .099 \\
\hline
\end{tabular}

As illustrated in Table 4, it shows that the value of significance to test the normality of the variable $\mathrm{Y}$ is 0,492 and 0,099 for the variable $\mathrm{Z}$. These values are $>0,05$, so that the data expressed in $\mathrm{Y}$ and $\mathrm{Z}$ are normally distributed.

The model will be described in two sub-structures as follows:

Sub structure $1: \mathrm{Y}=\mathrm{P}_{\mathrm{yx} 1} \mathrm{X}_{1}+\mathrm{P}_{\mathrm{yx} 2} \mathrm{X}_{2}+\varepsilon_{1}$

Sub structure $2: \mathrm{Z}=\mathrm{P}_{\mathrm{zy}} \mathrm{Y}+\varepsilon_{2}$

Description:

$\mathrm{Y} \quad=$ Accounting Information System Quality

$\mathrm{X}_{1} \quad=$ Top Management Supports

$\mathrm{X}_{2} \quad=$ Internal Control

$\mathrm{Z}=$ Accounting Information Quality

The Influence of the Top Management Support and of the Internal Control on the Implementation of Accounting Information System Quality

Model: Sub structure 1: $\mathrm{Y}=\mathrm{P}_{\mathrm{yx} 1} \mathrm{X}_{1}+\mathrm{P}_{\mathrm{yx} 2} \mathrm{X}_{2}+\varepsilon_{1}$ 
By using SPSS, it is obtained the path coefficients to find the value of $\mathrm{P}_{\mathrm{yx} 1}$ is 0.641 and of $\mathrm{P}_{\mathrm{yx} 2}$ is 0.423 . The following table shows the value of $\mathrm{R}^{2}$, that is the amount of simultaneous influences of variables $\mathrm{X}_{1}$ and $\mathrm{X}_{2}$ on $\mathrm{Y}$.

Table 4: Model Summary

\begin{tabular}{llllll}
\hline Model & $\mathbf{R}$ & R Square & $\begin{array}{l}\text { Adjusted } \\
\text { Square }\end{array}$ & $\begin{array}{l}\text { Std. Error of the } \\
\text { Estimate }\end{array}$ & the \\
\hline 1 & $.889^{a}$ & .723 & .756 & .3137 & \\
\hline
\end{tabular}

Predictors: (constant), $\mathrm{X}_{2}, \mathrm{X}_{1}$

Table 5 shows that the value of $\mathrm{R}^{2}=0.723$ of adjusted $\mathrm{R}^{2}=0.756$. It means that both variables - the top management supports and the internal control - have simultaneous effects on the accounting information system quality as many as $72,3 \%$. On the other hand, the remaining value $27,7 \%$ or more than 0.277 represents the influences of other variables that are not investigated.

Sub structure $1: \mathrm{Y}=0.641 \mathrm{X}_{1}+0.423 \mathrm{X}_{2}+0.723$

Furthermore, Table 6 shows the result of test of simultaneous hypothesis as follow.

Table 5: Test of Simultaneous Hypothesis

\begin{tabular}{llll}
\hline F Test & & & \\
\hline $\mathrm{F}_{\text {count }}$ & $\mathrm{F}_{\text {table }}$ & $\mathrm{p}$-value & Conclusion \\
51.094 & 2.8843 & 0.000 & $\mathrm{~F}$ count $>\mathrm{F}$ table $:$ significant \\
\hline
\end{tabular}

The table argues that the value of $\mathrm{F}_{\text {count }}$ is 51.094 ; the value will be statistic test compared with another value of $F$ in the table for $\alpha=0.05$. It is learnt that the value of $F_{\text {table }}$ is 2.8843 reached since the value of is

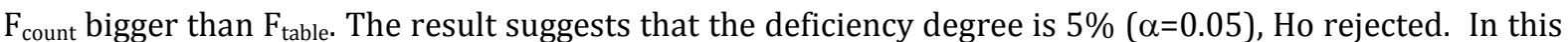
case, it is concluded that, with the trust reaches $95 \%$, both of the top management supports and the internal control have significant effects on the accounting information system quality in the Baitulmal Wattamwil (BMT) in West Java Indonesia.

Table 6: Test of Partial Hypothesis

\begin{tabular}{lllll}
\hline Variable & $\begin{array}{l}\text { T Test } \\
\text { t count }\end{array}$ & t tabel & p-value & Conclusion \\
\hline $\mathrm{X}_{1} \longrightarrow \mathrm{Y}$ & 4.6857 & 1.8742 & 0.011 & t count $>$ t table $:$ significant \\
$\mathrm{X}_{2} \longrightarrow \mathrm{Y}$ & 2.945 & 1.8742 & 0.032 & $\mathrm{t}$ count $>$ t table $:$ significant \\
\hline
\end{tabular}

Based on the table 7 , it is known that the test of partial hypothesis $X_{1}$ and $X_{2}$ yields significant results. This suggests that partially the top management support gives significant influences on accounting information system quality as well as the internal control providing significant partial effect on accounting information system quality.

The Influence of Accounting Information Quality on the Implementation of Accounting Information System

Model : Sub structure 2: $\mathrm{Z}=\mathrm{P}_{\mathrm{zy}} \mathrm{Y}+\varepsilon_{2}$

By using SPSS, it was learnt that the path coefficients obtain for $\mathrm{P}_{z y}$ values as follows:

Tabel 7: Coefficientsa

\begin{tabular}{|c|c|c|c|c|c|}
\hline \multirow[t]{2}{*}{ Model } & \multicolumn{2}{|c|}{$\begin{array}{l}\text { Unstandardized } \\
\text { Coefficients }\end{array}$} & $\begin{array}{l}\text { Standardized } \\
\text { Coefficients }\end{array}$ & $\mathbf{T}$ & Sig. \\
\hline & $\bar{B}$ & Std. Error & Beta & & \\
\hline (Constant) & 7.942 & 5.113 & & 1.793 & 145 \\
\hline & .674 & .063 & .841 & 12.338 & 00 \\
\hline
\end{tabular}

a. Dependent Variable: Z

Learning from the output, the value of $\mathrm{P}_{\mathrm{zy}}$ is 0.923 . The following is the value of $\mathrm{R}^{2}$ which is the amount of influences of the variable $\mathrm{Y}$ to $\mathrm{Z}$. 
Table 8: Model Summary

\begin{tabular}{lllll}
\hline Model & R & R Square & $\begin{array}{l}\text { Adjusted R } \\
\text { Square }\end{array}$ & $\begin{array}{l}\text { Std. Error of the } \\
\text { Estimate }\end{array}$ \\
\hline 1 & $.923^{\mathrm{a}}$ & .876 & .761 & .23678 \\
\hline
\end{tabular}

Predictors: (constant), Y

Table 9 describes that the value of $\mathrm{R}^{2}$ is 0.876 and the adjusted value of $\mathrm{R}^{2}$ is 0.761 . It means that the value of influences of accounting information system quality on the accounting information quality is $87,6 \%$ with remaining $12,4 \%$ or more than 0.124 (the influences of other variables not investigated).

Sub structure $2: \mathrm{Z}=0.923 \mathrm{Y}+0.124$

Table 9: Test of Hypothesis

\begin{tabular}{lllll}
\hline Variable & $\begin{array}{l}\text { T Test } \\
\text { t count }\end{array}$ & t tabel & p-value & Conclusion \\
\hline $\mathrm{Y} \longrightarrow \mathrm{Z}$ & 9.862 & 1.943 & 0.000 & t count $>$ t table $:$ significant \\
\hline
\end{tabular}

The table 10 shows that hypothesis test yields significant results. This suggests that the accounting information system quality significantly gives influence to the accounting information quality.

The Influence of the Top Management Support and of the Internal Control on the Accounting Information System Quality and Its Implication on the Accounting Information Quality in Baitulmal Wattamwil (BMT) in West Java Indonesia: As mentioned in the two-sub-structures analysis, the result of path-model research usually used to determine the magnitude of the direct or indirect influence of one variable on another variable, may be explained by Figure 2 .

Figure 2: The Result of Research Model Path Diagram

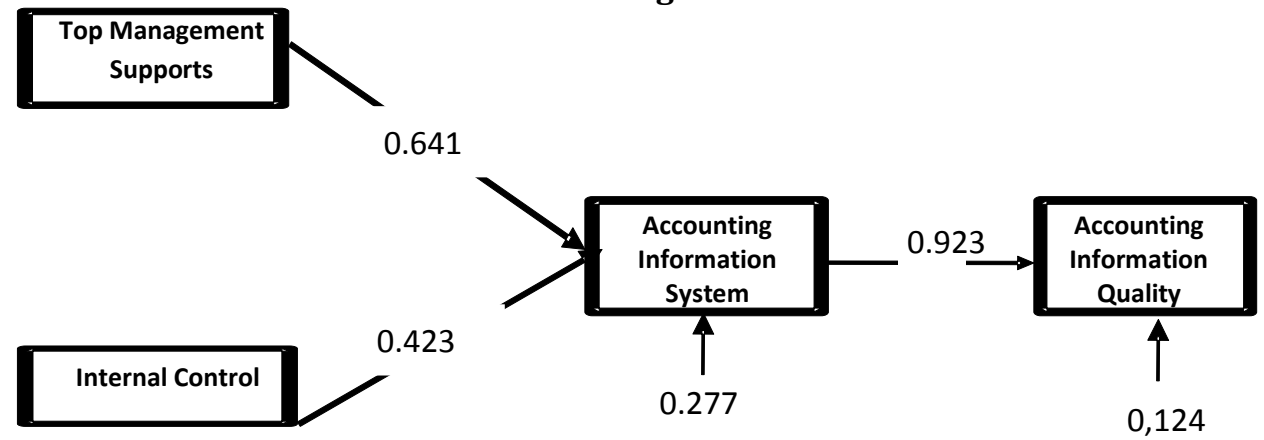

From Figure 2, it can be concluded that:

- The top management supports have significant influence to the accounting information system quality with the amount of influence of $56.7 \%$.

- The internal control has significant effect on the accounting information system quality with the amount of influence of $48.3 \%$.

- The top management supports and the internal control simultaneously have significant influence to the accounting information system with the amount of influence of $72.3 \%$.

- The accounting information system quality has significant influence to the accounting information quality with the amount of influence of $87.6 \%$.

- The top management support gives influences to the accounting information system quality and provides significant impact to the accounting information quality with the amount of influence of $0.641 \times 0.923 \times 100 \%=59.16 \%$.

- The internal control give influences to the accounting information system quality and provides significant impact to the accounting information quality with the amount of influence of $0.423 \times 0.923$ $\mathrm{x} 100 \%=39.04 \%$.

In conclusion, the results of the study supports the hypothesis suggested. First, the top management supports and the internal control give influences to the accounting information system quality. Finally, the accounting information system quality gives influence to the accounting information quality. It means 
that, to reach accounting information quality, Baitulmal Wattamwil (BMT) in West Java Indonesia must be supported by qualified accounting information system quality.

\section{Conclusion}

The top management supports and the internal control implemented in Baitulmal Wattamwil (BMT) have significant effects on the accounting information system quality both partially and simultaneously. In partial, the influences of the top management support variable on the accounting information system quality are more dominant than those of the internal control. Otherwise, in simultaneous, the accounting information system quality may be achieved if the optimalization of the top management support and the internal control is significantly executed.

Acknowledgements: Thank to Prof. Dr. Azhar Susanto, SE., M.Bus, Ak as my professor in UNPAD, Dr. Ir. Eddy Soeryanto Soegoto as the Rector of UNIKOM, and all of the people who cannot be mentioned individually. May Allah SWT give His blessing. Thank to my beloved family: my wonderful husband, parents and children who have motivated and supported me all this time.

\section{References}

Agus, M. (2010). Agus Marto Beberkan Kelemahan di Ditjen Pajak. www.buletininfo.com.

Ann, M., Michael, M. Y. \& Barbara, W. (2008). Achieving Top Management Support in Strategic Technology Initiatives. Current Issues in Technologi Management - Howe School Alliance For Technologi Management.

Anwar, N. (2007). BPK : Krisis Keuangan Global Harus Jadi Pelajaran. www.tempo.co.

Anwar, N. (2009). BPK : Laporan Keuangan Pemeritah Buruk. http://bisniskeuangan.kompas.com/read/2009/06/09/11503357/BPK.Laporan.Keuangan.Pem erintah.Buruk, 9 Juni 2009.

Azhar, S. (2008). Sistem Informasi Akuntansi, Struktur-Pengendalian-Resiko-Pengembangan. Bandung : Lingga Jaya.

Bhanu, N., Ragu, S., Apigiah, C. H., Ragu-Nathan, T. S. \& Qiang, T. (2004). A Path Analytic Study of The Effect of Top Management Support for Information System Performance. The International Journal of Management Science, 32(2).

Bodnar, G. H. \& Hopwood, W. S. (2010). Accounting Information System. New Jersey: Prentice Hall.

Chen, I. \& Paulraj, A. (2004). Towards of Theory of Supply Chain Management : The Constructand Measurement. Journal of Operations Management, 22, 119-150.

Choe, J. M. (1996). The Relationship Among Performance of Accounting Information Systems, Influence Factors, and Evolution Level of Information Systems. Journal of Management Information System, $12(4)$.

DeLone, W. H. \& McLean, E. R. (1992). Information System Success: The Quest of The Dependent Variable. Information Systems Research, 3, 60-95.

DeLone, W. H. \& McLean, E. R. (2003). The DeLone and McLean Model of Information System Succes : A Ten Years Update. Journal of Management Information System, 19(4), 3-30.

Difi, A. J. (2012). BI Tetapkan Sanksi Berat ke Bank Mega Akibat Pembobolan Dana. http://finance.detik.com/read/2011/05/24/185152/1646167/5/bi-tetapkan-sanksi-berat-kebank-mega-akibat-pembobolan-dana?query-string, 24 Mei 2011.

Doll, W. \& Deng, X. (2001). The Collaborative Use of Information Technology : End User Participation and System Succes. Information Resources Management Journals. ABI/INFORM Global.

Doll, W. J. (1985). Avenues for Top Management Involvement in Successful MIS Development. MIS Quart, $9(1), 17-35$

Elder, R. J., Mark, S. B. \& Alvin, A. A. (2010). Auditind and Assurance Sevices An Integrated Approach. NJ: Prentice-Hall

Eppler, M. J. (2003). Managing Information Quality: Increasing the Value of Information in KnowledgeIntensive Products and Processes. Heidelberg/New York: Springer.

Gelinas, J. R., Ulric, J., Dull, R. B. \& Wheeler, P. R. (2012). Accounting Information System. $9^{\text {th }}$ Edition. USA: South Western Cengage Learning.

Hadi, P. (2010). 8 Kementerian/Lembaga Masih Dapat Opini Disclaimer. http://finance.detik.com/read/2010/06/01/143338/1367540/4/8-kementerian, 1 Juni 2010.

Hadi, P. (2012). Sumatera Utara: BPK Sepakat Bangun Sistem E-Audit. http://indonesia.go.id. 
Halim, A. (2011). Pembobolan Bank di RI Mirip-mirip Kasus Pembobolan Beken di Dunia. http://finance.detik.com/read/2011/06/22/115753/1665876/5/pembobolan-bank-di-ri-

mirip-mirip-kasus-pembobolan-beken-di-dunia, 22 Juni 2011.

Hall, J. A. (2011). Accounting Information System. $7^{\text {th }}$ Edition: South-Western Publishing Co.

Hansen, D. R. \& Mowen, M. M. (1995). Cost Management Accounting and Control. South Western College Publishing.

Harun, A. R. (1994). Teknik Sampling dan Penskalaan. Universitas Padjadjaran : Bandung.

Hashmi, A. S. K. (2004). Gold Catalysis : The Benefits of Nand N, O Ligands

Herry, P. (2010). Kemenkeu 'Ikat' Instansi Pemerintah Perbaiki Laporan Keuangan.

Iceman, K. \& Hillson, L. (1990). Distribution of Audited Detected Errors Partitioned by Internal Control. Journal of Accounting, Auditing \& Finance, 5(4).

Indra, B. (2010). Akuntansi Sektor Publik Suatu Pengantar. Edisi Ketiga. Jakarta : Penerbit Erlangga.

Ivancevich, J. M., Konopaske, R. \& Matteson, M. T. (2011). Organizational Behavior and Management. Ninth Edition. New York: McGraw Hill. International Edition.

Jarvenpaa, S. \& Ives, B. (1991). Executive Involvement and Participation in The Management of Information Technology. MIS Quartely, 15(2), 205-227.

Kieso, D. E., Weygandt, J. \& Warfield, T. D. (2012). Intermediate Accounting. $14^{\text {th }}$ Edition. UK: John Willey and Sons, Inc.

Laudon, K. C \& . Laudon, J. P. (2014). Management Information Systems Managing The Digital Firm. Thirteenth Edition. America: Pearson Prentice Hall.

Mahring, M. (2002). IT Project Governance. Publisher: EFI at SSE.

Mark, H. I., Cindy, T. L. \& Jerry, W. L. (2012). Organizational Factors for Successful Implementation of Information System: Disentangling the Effect of Top Management Support and Training. Proceeding of The Southern Association for Information System Conference. USA.

McGill, T. (2003). User - Developed Applications and Information Systems Succes : A Test of DeLone and McLeans Model. Information Resources Management Journal, 16(1), 24-24 Jan-Mar.

McLeod, R. \& Schell, G. P. (2007). Management Information System. Tenth Edition. Upper Saddle River New Jersey 07458 : Pearson/Prentice Hall.

Messier, G. \& Prawitt, L. (2010). Auditing and Assurance Services: A Systematic Approach. 4th Edition. NY: McGraw-Hill.

Nash , J. F. \& Cynthia, D. H. (1993). Accounting Information Systems, 3 rd ed, South-Western Publishing Co.

Nicolaou, A. I. (2000). A Contingency Model of Perceived Effectiveness in Accounting Information Systems: Organizational Coordination and Control Effects. International Journal of Accounting Information Systems, 1(2), 91-105.

O’Brien, J. A. \& Marakas, G. M. (2008). Management Information Systems. Tenth Edition. New York: McGraw-Hill Irwin.

Stair, R. M. \& Reynolds, G. W. (2010). Principles of Information Systems, Course Technology. 9 ${ }^{\text {th }}$ Editions. New York : Mc-Graw-Hill.

Ramlah, H., Norshidah, M., Nor, S. A. K. \& Abdul, R. A. (2009). The Influences Organizational Factors on Information System Success in E-Government Agencies in Malaysia. The Electronic Journal of Information System in Developing Countries. http://www.ejisdc.org.

Raymond, C. Y. (2006). Explaining Senior Management Support Through IT Project Governance

Robbins, S. P. \& Coulter, M. (2012). Management. Twelfth Edition. USA: Pearson Education Limited.

Romney, M. B. \& Steinbart, P. J. (2012). Accounting Information Systems. Global Edition. Twelfth Edition. England: Pearson Education Limited

Sacer, I. M., Zager, K. \& Tusek B. (2006). Accounting Information System's Quality as The Ground For Quality Business Reporting. IADIS International Conference e-commerce, 972-8924-23-2.

Scott, G. M. (2001). Principles of Management Information System. New York : McGraw-Hill, Inc.

Sheth, S. (2010). Ten Things That Indicate Top Management Support for Business Continuity. Continuity Central.

Sharma, R. \& Yetton, P. (2003). The Contingent Effect of Management Support and Task Interdependence on Successful Information Systems Implementation. MIS Quartely, 27(4).

Shead, S. (2002). What Is Senior Management Commitment. Copyright@2002. Software Productivity Consortium NFP, Inc. All right resrved.

Shebab, E. M. (2004). Enterprise Resources Planning An Integrative Review. Business Process Management Journal, 10(4), 359-386.

Shipper, K. \& Vincent, L. (2003). Earning Quality. Accounting Horizons, Supplemen, 97-110.

Stacie, P., William, D. \& Ephraim, M. (2008). Measuring information system success: models, dimension, measures, and Interrelationships. European Journal of Information System, 2(2). 
Taufikurahman, R. (2011). Kenegarawanan: Demokrasi Kita Berbau Kriminal. http://jakarta45.wordpress.com/2011/03/30/kenegarawanan-rezim-sby-lakukan-duamanipulasi-besar/, 26 Maret 2011.

Uchok, S. K. (2012). Perusahaan BUMN Masih Takut Transparansi Laporan Keuangan. http://www.tempo.co/read/newstempobisnis, 16 Juli 2012.

Wang, R. Y. \& Strong, D. M. (1996). Beyond Accuracy: What Data Quality Means to Data Consumers. Journal of Management Information Systems, 12(4), 5-33.

Wilkinson, J. W., Cerullo, M. J., Raval, V. \& Bernard, W. O. W. (2000). Accounting Information Systems Essential Concepts and Applications. Fourth Edition. USA: John Wiley and Sons Inc.

Wixom, B. H. \& Todd, P. A. (2005). A Theoretical Integration of User Satisfaction and Technology Acceptance. Information Systems Research, 16(1), 85-102.

$\mathrm{Xu}$, H., Nord, H. J. \& Lin, B. (2003). Key Issues Accounting Information Quality Management : Australian Case Studies. Industrial Management and Data System.

Zimmerman, J. (1995). Accounting for Decision Making and Control. Chicago : Irwin.

Zviran, M., Pliskin, N. \& Levin, R. (2005). Measuring User Satisfaction and Perceived Usefulness in The ERP Context. Journal of Computer Information Systems, 45(3), 43-52. 